\title{
Evaluation of the Acceptance of the Developer Registration System Using the TAM Framework with the Perspective of Housing Developers and Associations in Indonesia
}

Evaluasi Penerimaan Sistem Registrasi Pengembang Menggunakan Kerangka Kerja TAM dengan Perspektif Asosiasi dan Pengembang Perumahan di Indonesia

Received:

15 June 2020

Accepted:

13 December 2020

Published:

1 February 2021

\author{
${ }^{1 *}$ Yekti Wirani, ${ }^{2}$ Elsa Nadira, ${ }^{3}$ M. Syaiful Romadhon \\ ${ }^{1,2,3}$ Sistem Informasi, Sekolah Tinggi Teknologi Terpadu Nurul Fikri \\ ${ }^{1,2,3}$ Depok, Indonesia \\ E-mail:1yekti@nurulfikri.ac.id, 2elsanadira@gmail.com, \\ syaiful@nurulfikri.ac.id
}

*Corresponding Author

\begin{abstract}
The Developer Registration System (SIRENG), owned by the Ministry of Public Works and Public Housing of the Republic of Indonesia, aims to provide supervision on the quality of houses built by housing developers. Based on the interviews with the association manager PERWIRANUSA, the completeness and suitability of the information in SIRENG are still limited. It does not meet SIRENG development benefits, guaranteeing that registered developers in SIRENG are experienced and trusted. This study aims to provide recommendations for managers of SIRENG to improve the system through evaluation of acceptance of SIRENG with the association and housing developer's perspective. This study uses the Technology Acceptance Model (TAM) framework and utilizes PLS techniques to analyze respondents' data. This study used a mixed-method. This study's results are Perceived Ease of Use, Perceived Usefulness, Attitude Toward Using, and Actual Usage (AU) variables that influence the acceptance of SIRENG.

Keyword-Housing Developer Registration Systems, Electronic Government, TAM, Partial Least Square

Abstrak-Sistem Registrasi Pengembang (SIRENG) yang dimiliki oleh Kementerian Pekerjaan Umum dan Perumahan Rakyat (PUPR) bertujuan untuk memberikan pengawasan pada kualitas rumah yang dibangun oleh pengembang perumahan. Berdasarkan hasil wawancara dengan pengelola asosiasi PERWIRANUSA, kelengkapan dan kesesuaian informasi di SIRENG masih terbatas. Ini belum memenuhi manfaat pengembangan SIRENG, yaitu memberikan jaminan pengembang terdaftar di SIRENG telah berpengalaman dan terpercaya. Penelitian ini bertujuan untuk memberikan rekomendasi bagi pengelola SIRENG untuk melakukan perbaikan sistem melalui evaluasi penerimaan pada SIRENG dengan perspektif asosiasi dan pengembang perumahan. Penelitian ini menggunakan kerangka kerja TAM dan memanfaatkan teknik PLS untuk menganalisis data yang dihasilkan dari responden. Penelitian ini menggunakan mixed-method. Hasil dari penelitian ini adalah Perceived Ease of Use, Perceived Usefulness, Attitude Toward Using, dan Actual Usage (AU) merupakan variabel yang memengaruhi penerimaan SIRENG.
\end{abstract}

Kata Kunci-Sistem Registrasi Pengembang, Electronic Government, Technology Acceptance Model, Partial Least Square

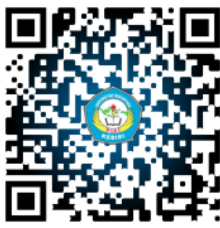

INTENSIF: Jurnal Ilmiah Penelitian dan Penerapan Teknologi Sistem Informasi 
INTENSIF, Vol.5 No.1 February 2021

ISSN: 2580-409X (Print) / 2549-6824 (Online)

DOI: https://doi.org/10.29407/intensif.v5i1.14477

\section{INTRODUCTION}

In 2018, the Ministry of Public Works and Public Housing (PUPR) launched the Developer Registration System (Sistem Registrasi Pengembang/SIRENG) application that supports the construction of subsidized housing [1]. The SIRENG application is managed by the Center for Housing Finance Fund Management (Pusat Pengelolaan Dana Pembiayaan Perumahan/PPDPP) under the Directorate General of Homework Infrastructure Financing [2]. The existence of SIRENG is intended to provide supervision on the quality of subsidized houses built by the developers of the company to conform to the standards of livable homes [1]. SIRENG can be accessed on the page https://sireng.pu.go.id. People who want to find out information about housing developers can use SIRENG to ensure that developers have registered and validated at the Ministry of PUPR [1].

Based on the interviews with the managers of SIRENG in June 2019, it was found that there were no evaluations of the use of SIRENG, including benefits, functions, convenience, and clarity of information. Also, the suitability of the information needed by the user for SIRENG is not yet known. In addition to conducting interviews with the managers of SIRENG, this study also conducted interviews with the association manager of the Rumah Rakyat Nusantara Entrepreneur Association (PERWIRANUSA) in July 2019 to ensure clarity and appropriateness of information regarding housing developers in SIRENG. This interview found that SIRENG information was not yet complete, and the lack of information regarding the history and location of housing developers. This information is essential to ensure that housing developers registered with SIRENG are experienced and trustworthy developers. Also, housing developers feel that with the limited information available on SIRENG and difficulties accessing SIRENG, the community will have trouble obtaining trusted developers' knowledge.

Based on the problems raised by the management of SIRENG and the housing development association's manager, it is necessary to evaluate the acceptance of SIRENG. This study analyzes SIRENG collection's approval from PERWIRANUSA associations and housing developers using the Technology Acceptance Model (TAM) framework. The benefits of this research are the managers of SIRENG get useful information to improve the quality of SIRENG. In contrast, housing associations and developers get clarity and suitability of data placed in SIRENG according to the community's needs, namely the track record of housing developers.

Various theories regarding the acceptance of technological innovation at the individual level have been widely researched, such as TAM, The Innovation Diffusion Theory (IDT), The Theory of Reasoned Action (TRA), The Theory of Planned Behavior (TPB), and The Unified Theory of Acceptance and Use of Technology (UTAUT). TAM was developed by [3] in 1985, which 
analyzes system characteristics based on user acceptance of information systems. The TAM theory forms the basis for the practice of user acceptance testing. The IDT theory was developed by [4] in 1962 and stated that the diffusion process is communicated over time in the social system. The TRA theory was developed by [4] in 1975. The approach developed is based on attitude, persuasion models, and social psychology. The TPB theory was developed by [5] in 1991 by combining attitude theory, perceived behavioral control, and subject norms. UTAUT theory was developed by [6] in 2003. This theory creates four primary constructs: effort expectancy, performance expectancy, social influence, and facilitating conditions.

This study uses TAM because it is a robust and established framework for analyzing information system design problems and predicting technology acceptance by its users [7]. Also, TAM is an appropriate framework used to measure acceptance in individuals [8]. In this context, the Developer Association found problems with limited information and difficulties accessing SIRENG so that the community didn't feel the benefits of SIRENG. In the context of this research, TAM is appropriate because it has components of Perceived Usefulness and Perceived Ease of Use, which are used to analyze problems in association members. Besides, several previous studies have used TAM to evaluate acceptance in electronic government [9]. This study uses four construct variables from TAM, namely Perceived Ease of Use (PEOU), Perceived Usefulness (PU), Attitude Toward Using (ATU), and Actual Use (AU), which are represented in the questions in the questionnaire to be distributed to the housing developers. The questionnaire results will be processed using SmartPLS software based on Partial Least Square (PLS) statistical techniques.

This study uses literature studies that include electronic government, TAM, and PLS. Electronic government is a government service to citizens and businesses that use information technology and allows interaction between other parties with the government [10]. According to the European Commission, if the electronic government is appropriately implemented, it can increase government and business savings and provide convenience for citizens [11].

TAM is a framework developed by Davis in 1989 to measure acceptance, widely used to understand human behavior using technology [12]. According to [12][3], PU is defined as the user's perception of the benefits obtained when using technology. Whereas PEOU is considered as the user's perception of the ease felt when using technology. ATU is defined as the attitude of technology users who show rejection or acceptance, and AU is considered an external psychometric response that can be measured from actual use.

PLS is a multivariate statistical technique comparing dependent and independent variables in multiple ways [13]. PLS has the advantage of assessing models with a small sample size [14]. PLS aims to predict the influence of one variable with another and explain the theoretical 
INTENSIF, Vol.5 No.1 February 2021

ISSN: 2580-409X (Print) / 2549-6824 (Online)

DOI: https://doi.org/10.29407/intensif.v5il.14477

relationship between the two variables [13]. Besides, this study uses the PLS technique because this research model is a formative construct. Formative construct form is connecting the secondorder construct with the first order as the indicator [14].

Previous studies evaluating acceptance in electronic government using the TAM framework were used as supporting research in this study. Research conducted by [15] uses TAM to analyze the endorsement of mobile government services. The results of this study are that PEOU affects the satisfaction of mobile government users. Research conducted by [16] using electronic retribution (e-retribution) as an innovation of smart governance in Surakarta also uses the TAM framework. This study aims to evaluate the acceptance of traditional market traders towards the use of e-retribution. This study's results are PU and PEOU positively impacting AU, and Behavioral Intention (BI) harms $\mathrm{AU}$. The suggestion given by this research is that the government needs to provide a help desk in traditional markets to support the use of e-retribution. Meanwhile, other research conducted by [17] on a smartphone-based survey system managed by the National Population and Family Planning Agency (BKKBN) also uses TAM as an acceptable framework. This study aims to evaluate user acceptance of the BKKBN survey system. The results of this study are that PEOU has a positive effect on PU and ATU, PU has a positive impact on ATU, ATU has a positive impact on BI, and BI has a positive impact on the AU. Research conducted by [18] combines TAM with environmental sustainability as an external variable to evaluate the acceptance of electronic government services in Peru. This study's ecological sustainability, PEOU, PU, and ATU are the main factors that influence Peruvian citizens to use electronic government services. Meanwhile, research conducted by [9] evaluates factors that are important for increasing the acceptance of government services in Egypt by using TAM. The results of this research confirm that Website Design, Trust in Government, Perceived Public Value, Trust in the internet, PU, PEOU, ATU, BI, and AU are valid measures for assessing the success of electronic government acceptance.

\section{RESEARCH METHOD}

This study developed a model that was adapted from previous studies. Previous studies used the TAM framework as an acceptance model in electronic government. This study presents a renewal of acceptance evaluation availability in electronic government systems that provide information on housing developers in Indonesia. The availability of a housing developer information system that offers complete information can avoid fictitious housing developers that harm the community and other developers. The variables used as acceptance models in SIRENG are presented in Table 1. Based on Table 1, there are four variables to be examined in this study, 
namely PEOU, PU, ATU, and AU. This study develops four variables obtained from previous research. Not all variables in the literature are used in this study. Researchers did not use the BI variable because the participants in this study desired to use SIRENG. The BI variable is expressed as an intention to use a technology [17].

Table 1. The Variables Used as ACCePtAnCe MOdels

\begin{tabular}{ll}
\hline \hline Variables & Sources \\
\hline Perceived Ease of Use (PEOU) & {$[9][15][16][17]$} \\
\hline Perceived Usefulness (PU) & {$[15][16][17][18]$} \\
\hline Attitude Toward Using (ATU) & {$[9][17]$} \\
\hline Actual Usage (AU) & {$[17]$} \\
\hline
\end{tabular}

The hypotheses developed in this study are built from the TAM framework. According to [19], PU is interpreted as a level of confidence that the technology can provide all the information needed. In this study, PU is represented as a benefit of SIRENG to find housing developer information [15][16][17], find information quickly [15], there are no restrictions in accessing SIRENG [18], and SIRENG makes work easy [15]. The benefits offered by SIRENG are believed to encourage the emergence of a positive attitude in the use of SIRENG.

According to [19], PEOU is defined as the level of belief that the technology used is free from mental burdens. PEOU in this study is represented as SIRENG's ease of finding developer information [9][16], ease of operation [17], and ease of access anywhere and anytime $[9][15][17]$. The convenience offered by SIRENG is expected to provide a positive attitude to the use of SIRENG. Other research variables used in this study are ATU and AU. In this study, ATU is represented as user pleasure when using SIRENG [9][17], the need to use SIRENG [17], and the decision to use SIRENG is an excellent idea [17], precise and wise [9][17].

A user who feels pleasure and needs when using SIRENG can keep using SIRENG when looking for housing developer information. According to [17], AU is represented as the satisfaction of information obtained from SIRENG. Besides, AU is also described as a condition of users who often use SIRENG to find subsidized housing developers. Based on these explanations, People can see the model used in this study in Figure 1. Figure 1 explains that this study will analyze the influence of the PEOU and PU variables on ATU and the ATU variable's impact on AU. The research will develop the analysis in the form of three hypotheses. Hypotheses developed in this study include Hypothesis 1 (H1), Hypothesis 2 (H2), and Hypothesis 3 (H3), which are described as follows:

H1: Perceived Ease of Use (PEOU) affects Attitude Toward Using (ATU)

H2: Perceived Usefulness (PU) affects Attitude Toward Using (ATU)

H3: Attitude Toward Using (ATU) affects Actual Usage (AU) 
INTENSIF, Vol.5 No.1 February 2021

ISSN: 2580-409X (Print) / 2549-6824 (Online)

DOI: https://doi.org/10.29407/intensif.v5i1.14477

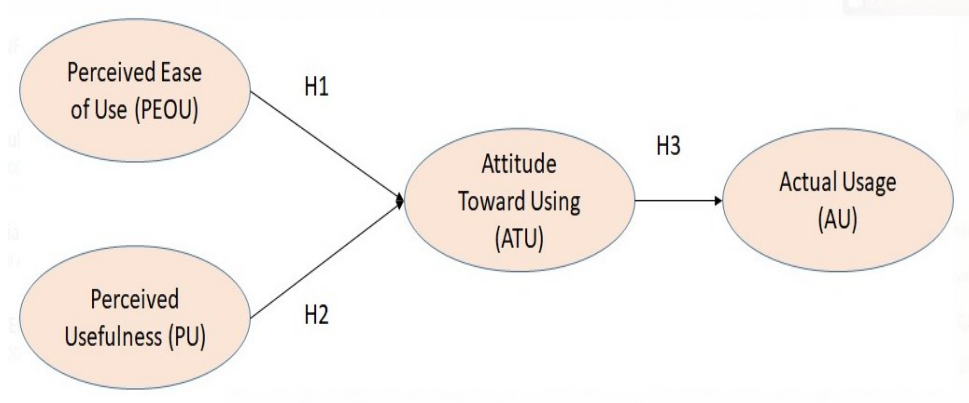

Figure 1. RESEARCH MODEL

In this study, researchers carried out a series of stages. The steps of the study are presented in Figure 2. Figure 2 shows that this research consists of seven stages. These stages are problem identification, literature review, hypothesis formulation, questionnaire formation from previous studies, data collection from respondents, data processing, and data analysis using Smart PLS. Results from this research are providing recommendations by the conditions in SIRENG.

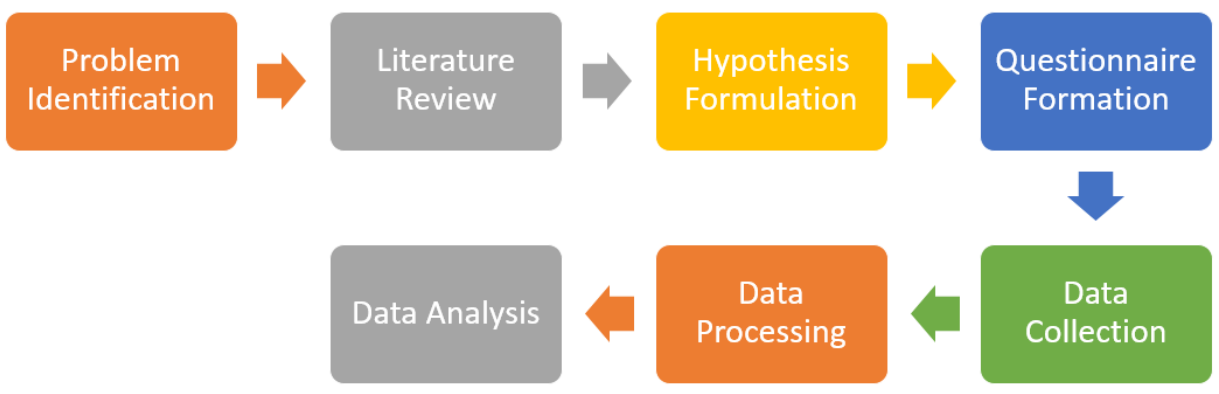

Figure 2. RESEARCH STAGES

A. Stages of Problem Identification and Literature Review

The activity stages of problem identification include the determination of the problem at SIRENG. This activity is carried out through interviews with managers of SIRENG from the Ministry of PUPR, interviews with PERWIRANUSA associations, and observations on SIRENG. Observations made on SIRENG include observations on the presentation of SIRENG's main page and the production of information search results on SIRENG. You can see the output of SIRENG's main page in Figure 3. The display in Figure 3 is the main display that can be accessed from the community. Association members and the community who want to find information about housing developers can search with keywords from the Taxpayer Identification Number, Developer ID, or Developer Name. 


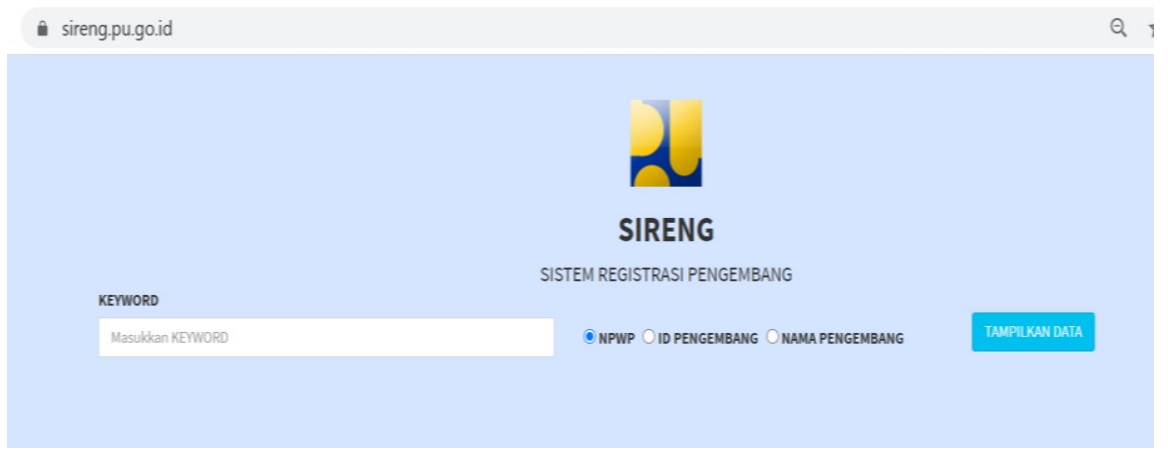

\section{The PRESENTATION OF SIRENG'S MAIN PAGE}

Figure

The next stage is a literature review that examines the theories that form the basis of research, including the TAM theory, electronic government, and previous studies using TAM in electronic government.

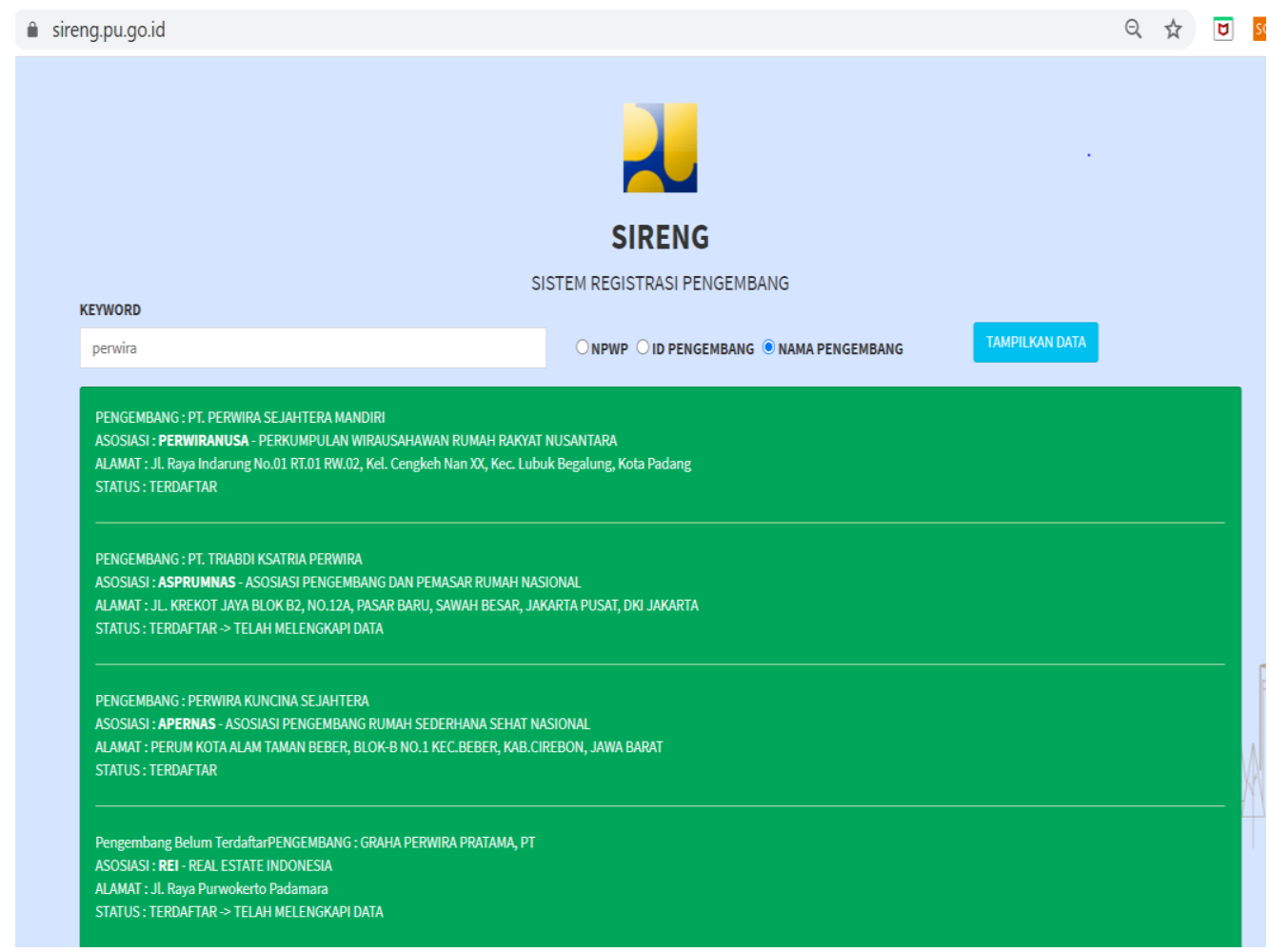

Figure 4. The Presentation of SEARCh Results Based on The DeVEloper's Name

B. Stages of Hypothesis Formulation and Questionnaire Formation

After the theories and research are reviewed, the hypothesis formulation will be carried out. The hypothesis is developed based on a determined framework that uses TAM. After the thesis is 
INTENSIF, Vol.5 No.1 February 2021

ISSN: 2580-409X (Print) / 2549-6824 (Online)

DOI: https://doi.org/10.29407/intensif.v5i1.14477

determined, the authors begin compiling the questionnaire. People can see the questionnaire of this research in Table 2. After this questionnaire was collected, the authors conducted a readability test on three prospective respondents. The readability test is intended to determine respondents' understanding and interpretation of the questionnaire's terms or statements [14].

Researchers developed the instrument in this study from a literature review. It consisted of 14 indicators used to assess the PEOU, PU, ATU, and AU variables, as in Appendix A. Indicators obtained from previous studies have a common framework. These indicators will be tested using validity and reliability testing. The questionnaire distributed to respondents consisted of two parts. The first part consists of statements related to respondents' demographics, while the second part contains statements to obtain variables from the study. This study uses a Likert scale to measure variables at intervals of 1 to 4 . Scale 1 for words interpreted as strongly disagree and scale four as strongly agree.

\section{Stages of Data Collection, Processing, and Analysis}

The next stage is the questionnaire distributed to the housing developers under the association PERWIRANUSA who have become users of SIRENG. The sample of this study reached 30 respondents from a total population of 80 people. The sample calculation uses the Slovin theory to determine the minimum number of respondents used in this study. The error used to measure the sample is $5 \%$, so the respondents' minimum number is 27 . After the questionnaire results are obtained, data is processed using the PLS technique. In this study, the software used to process information is SmartPLS v.3.2.6. This study uses PLS to analyze data by assessing the developed models' validity, reliability, and hypotheses.

\section{RESULT AND DISCUSSION}

This section will discuss the results of processing and analyzing research data.

\section{A. Demographics of Respondents}

There were 30 respondents involved to fill out the questionnaire in this study. Questionnaires placed on Google Forms are distributed online using Whatsapp to housing developers and associations. Respondents from Jakarta filled out the questionnaire, Bogor, Depok, Tangerang, Bekasi (Jabodetabek), West Java (excluding Bogor, Depok, and Bekasi), Central Java, East Java, Papua, Bali \& West Nusa Tenggara (NTB), Kalimantan, and Sumatra. Most respondents have used SIRENG for 1 to 6 months. The demographics of respondents are presented in Table 2 .

B. The Evaluation of Measurement Model 
The measurement model's evaluation is done by analyzing the outer and inner models through the PLS algorithm's measurement results. The researchers can do external model analysis by measuring discriminant validity, convergent validity, and composite reliability.

Table 2. RESPONDENT'S DEMOGRAPHY

\begin{tabular}{clll}
\hline \hline Variable & Measure & Sample & Percentage (\%) \\
\hline \multirow{4}{*}{ Domicile } & Jabodetabek & 19 & 64 \\
\cline { 2 - 4 } & West Java & 1 & 3 \\
\cline { 2 - 4 } & East Java & 4 & 13 \\
\cline { 2 - 4 } & Papua & 0 & 0 \\
\cline { 2 - 4 } & Bali \& NTB & 1 & 3 \\
\cline { 2 - 4 } Period of Use $\boldsymbol{*}$ & Kalimantan & 5 & 17 \\
\cline { 2 - 4 } & $1-6$ months & 18 & 61.3 \\
\cline { 2 - 4 } & $7-12$ months & 9 & 28.9 \\
\hline \multirow{3}{*}{ >12 months } & 3 & 9.8 \\
\hline
\end{tabular}

According to [20], it can be analyzed from the loading factor value and the Average Variance Extracted (AVE) square root to assess convergent validity. The measurement model is categorized as passing the convergent validity test if the loading factor value is higher than 0.70 , and the AVE square root value is more significant than 0.50. Four indicators must be deleted when analyzing the loading factor value because the loading factor value is less than 0.70 . These indicators are PEOU1, PEOU3, PU4, and AU3. The analysis of the AVE root value is that no factor has an AVE root value of less than 0.50. People can see the loading factor and AVE root values in Table 3.

Discriminant validity can be measured by analyzing the value of cross-loading on each indicator. The cross-loading value of each indicator for the construct must be higher than the other constructs [14]. When evaluating the importance of cross is loading. Researchers found that all indicators in this study had higher values of its construct compared to other constructs. The research model has passed the discriminant validity test. Testing to ensure The researchers can do the construct's reliability by analyzing the value of Composite Reliability (CR) and Cronbach Alpha (CA). The measurement model is categorized as passing the reliability test if the CR and CA value is higher than 0.70 [21]. People can see CR and CA values in Table 3. 
INTENSIF, Vol.5 No.1 February 2021

ISSN: 2580-409X (Print) / 2549-6824 (Online)

DOI: https://doi.org/10.29407/intensif.v5i1.14477

Table 3. THE RESULTS OF VALIDITY AND RELIABILITY TESTING

\begin{tabular}{|c|c|c|c|c|c|}
\hline Construct & Indicator & $\begin{array}{l}\text { Loading } \\
\text { Factor }\end{array}$ & $\sqrt{ } \mathbf{A V E}$ & $\mathbf{C A}$ & $\overline{C R}$ \\
\hline \multirow{3}{*}{ PEOU } & PEOU1 & -0.235 & 0.857 & 1.000 & 1.000 \\
\hline & PEOU2 & 0.894 & & & \\
\hline & PEOU3 & 0.612 & & & \\
\hline \multirow{4}{*}{$\boldsymbol{P U}$} & PU1 & 0.793 & 0.842 & 0.780 & 0.872 \\
\hline & PU2 & 0.820 & & & \\
\hline & PU3 & 0.743 & & & \\
\hline & PU4 & 0.632 & & & \\
\hline \multirow{4}{*}{$A T U$} & ATU1 & 0.868 & 0.639 & 0.880 & 0.917 \\
\hline & ATU2 & 0.856 & & & \\
\hline & ATU3 & 0.876 & & & \\
\hline & ATU4 & 0.825 & & & \\
\hline \multirow[t]{3}{*}{$\boldsymbol{A U}$} & AU1 & 0.913 & 0.750 & 0.871 & 0.939 \\
\hline & AU2 & 0.927 & & & \\
\hline & AU3 & 0.662 & & & \\
\hline
\end{tabular}

C. The Evaluation of Structural Model

After testing the validity and reliability, then the next PLS is used to evaluate the inner model. Evaluation of internal models is also called structural evaluation models that can be assessed using R2 and path coefficients [22]. The value of R2 indicates the predictive power of the structural model [23]. $R^{2}$ also shows the suitability of the sample obtained with the model. The value of $R^{2}$ has a range of deals from 0 to 1 , with a model that has high accuracy will have a higher value [20]. People can see the $R^{2}$ value of the research model in Figure 5.

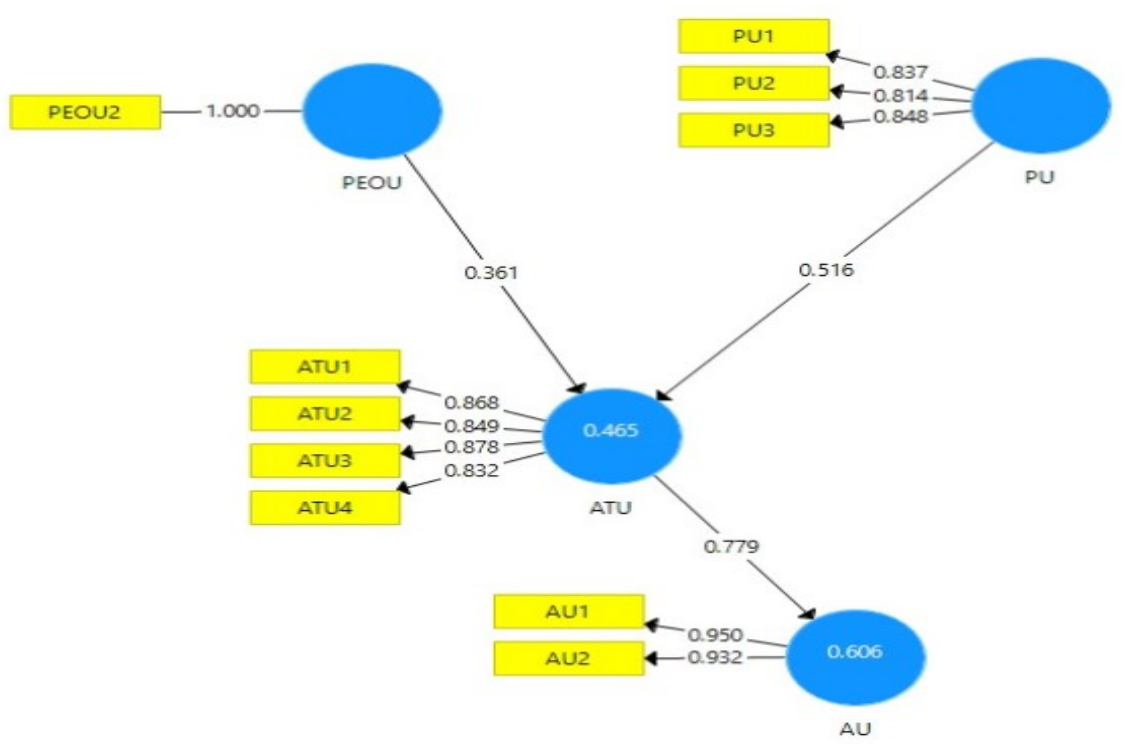

Figure 5. THE MEASUREMENT RESULT OF RESEARCH MODEL 
The ATU's $R^{2}$ value is 0.465 , which means that the variability value of the ATU construct explained through the PEOU and PU constructs is $46.5 \%$. In comparison, the remaining $54.5 \%$ is explained by other constructs not examined in this research. While the $R^{2}$ value of the AU construct is 0.606 , the variability value of the AU construct defined through the ATU construct is $60.6 \%$, while other constructs outside this study describe the remaining $39.4 \%$.

\section{Hypothesis Testing}

This study uses a two-tailed hypothesis testing type because the relationship of the hypothesis's direction is still unknown and will only be tested in this research. This study also uses a significance level of 0.05 , set on the bootstrap calculation in the SmartPLS software, so the t-value must be higher than 1.64. The results of hypothesis testing are shown in Table 4. Based on the hypothesis testing results, The researchers can conclude that PEOU and PU are proven to affect ATU, and ATU is proven to affect AU.

Table 4. HYPOTHESIS TESTING RESULTS

\begin{tabular}{cclll}
\hline \hline Hypothesis & Description & Path Coefficient & t-value & Result \\
\hline H1 & PEOU $\rightarrow$ ATU & 0.031 & 2.158 & Accepted \\
\hline H2 & PU $\rightarrow$ ATU & 0.000 & 3.647 & Accepted \\
\hline H3 & ATU $\rightarrow$ AU & 0.000 & 7.823 & Accepted \\
\hline
\end{tabular}

\section{E. Discussion}

The hypothesis testing results of this study are Perceived Ease of Use proven to affect the Towards Use. This result is similar to research conducted by [9]. As long as the user believes that using the SIRENG service to find housing developer information is easy, it will increase the user's attitude when using SIRENG. The benefits obtained by the user will encourage a positive attitude toward the acceptance of SIRENG. Other studies that have similar results are [16]. In addition to ease of use, ease of operation can support the user's attitude to using SIRENG. SIRENG is believed to be easy to use because users can search for information on subsidized housing developers through NPWP, ID, or the name of a subsidized housing developer. After the search is found, the user can see a list of housing developers by keyword based on the three searches above. Besides, SIRENG is expected to be accessible to users anytime, anywhere, and using any device.

Meanwhile, Perceived Usefulness has been proven to influence Attitude Toward Use. These research results are similar to the study conducted by [9] and [17]. The benefits offered by technology can support the emergence of a positive attitude toward the use of technology. The advantages offered by SIRENG to find information on housing developers who have registered with the Ministry of PUPR encourage positive attitudes of users to use SIRENG. SIRENG users 
INTENSIF, Vol.5 No.1 February 2021

ISSN: 2580-409X (Print) / 2549-6824 (Online)

DOI: https://doi.org/10.29407/intensif.v5i1.14477

believe that the existence of SIRENG makes it easy to work, that is, to get certainty that housing developers have registered with the Ministry of PUPR. With the availability of SIRENG, users will benefit from knowing housing developer information that has been registered at the Ministry of PUPR and has completed data relating to the legality of the developer. Complete developer information will prevent users from avoiding fictitious housing developers and do not have legality and validity to commit fraud to users.

The results of this study also confirm that attitude toward use affects actual usage. This result is in line with research conducted by [17]. The positive attitude of the user when using SIRENG will encourage the desire to continue to use SIRENG. This positive attitude can be shown when the user will search for information about the housing developer, and then the user will choose to use SIRENG compared to other methods. Users will continue to use SIRENG to find information on the subsidized housing developers.

\section{CONCLUSION}

This study confirms that the Perceived Ease of Use, Perceived Usefulness, Attitude Toward Use, and Actual Usage are variables that affect the acceptance of SIRENG. The manager of SIRENG needs to improve information relating to the developer of subsidized housing so that users feel the benefits. The perceived benefits relate to the completeness of the information provided by SIRENG, especially information about the developer's history. Completeness of information will reduce the possibility of users choosing irresponsible developers. Besides, managers of SIRENG need to ensure that SIRENG is easy to use and operate wherever and whenever users need it. These benefits and convenience will encourage the user's upbeat attitude when using SIRENG and affect the user's desire to continue using SIRENG. This research has a weakness that is the number of respondents involved is relatively small. Suggestions that can be given for the next research are increasing the number of respondents and engaging the community's perspective as prospective subsidized housing suppliers. This study also suggests that future studies can use other variables such as Security, Trust, and Information Quality. Besides, subsequent research can also use other theories such as The Unified Theory of Acceptance and Use of Technology (UTAUT) or the Theory of Planned Behavior (TPB). 


\section{REFERENCES}

[1] Kementerian Pekerjaan Umum dan Perumahan Rakyat, "Terdapat, 11.697 Pengembang yang Terdaftar di Sireng Kementerian PUPR,” Web PPDPP.id, 2019. [Online]. Available: $\quad$ https://ppdpp.id/terdapat-11-697-pengembang-yang-terdaftar-di-sirengkementerian-pupr/. [Accessed: 12-May-2020].

[2] Persatuan Perusahaan Real Estat Indonesia, "Baru 11.789 Pengembang Terdaftar di SIRENG," Web rei.orid, 2019. [Online]. Available: http://rei.or.id/newrei/berita-baru11789-pengembang-terdaftar-di-sireng.html. [Accessed: 12-May-2020].

[3] F. D. Davis, A Technology Acceptance Model for Empirically Testing New End-User Information Systems. Massachusetts Institute of Technology, 1985.

[4] E. M. Rogers, Diffusion of Innovations: 1st edition. Glencoe: Free Press, 1962.

[5] I. Ajzen, "The theory of planned behavior," Organizational Behavior and Human Decision Processes, vol. 50, no. 2, pp. 179-211, 1991.

[6] V. Venkatesh, M. G. Morris, G. B. Davis, and F. D. Davis, "User acceptance of information technology: Toward a unified view," Source MIS Quarterly, vol. 27, no. 3, pp. 425-478, 2003.

[7] S. A. Kamal, M. Shafiq, and P. Kakria, "Investigating acceptance of telemedicine services through an extended technology acceptance model (TAM)," Technology in Society, vol. 60, 2020.

[8] T. Oliveira and M. Martins, "Literature review of information technology adoption models at the firm level," Electronic Journal Information Systems Evaluation, vol. 14, no. 1, pp. 110-121, 2011.

[9] S. Elkheshin and N. Saleeb, "A conceptual model for E-government adoption in Egypt, "Proceedings of 2016 11th International Conference on Computer Engineering and Systems, ICCES 2016, pp. 254-259, 2017.

[10] S. Nunes, J. Martins, F. Branco, R. Goncalves, and M. Au-Yong-Oliveira, "An initial approach to e-government acceptance and use: A literature analysis of e-Government acceptance determinants, "Iberian Conference on Information Systems and Technologies, CISTI, 2017.

[11] European Comission, "eGovernment \& Digital Public Services," Web European Comission, 2019. [Online]. Available: https://ec.europa.eu/digital-singlemarket/en/public-services-egovernment. [Accessed: 12-May-2020].

[12] E. Fernando and L. M. Tirtamulia, "User behavior adopt utilizing FinTech services on online transportation in Indonesia (scale validation and developed instrument)," 2018 International Conference on Information Management and Technology (ICIMTech), pp. 114-118, 2018.

[13] H. M. Jogiyanto and W. Abdillah, Konsep dan Aplikasi PLS (Partial Least Square) untuk Penelitian Empiris, 3rd ed. Yogyakarta: BPFE-Yogyakarta, 2017.

[14] Y. M. Sari, B. Purwandari, R. Satria, Y. Wirani, I. Solichah, and T. I. Nastiti, "Factors Influencing Users Acceptance of Online Consultation Feature on the SOBAT-UKM Portal," 2018 International Conference on Information Technology Systems and Innovation, ICITSI 2018 - Proceedings, pp. 278-283, 2018.

[15] R. Bilkova and A. Kralova, "Adoption model of m-government services," P Proceedings of the International Conference on Information and Digital Technologies, IDT 2017, pp. 52-55, 2017.

[16] R. A. Nugroho, K. S, I. D. A. Nurhaeni, and W. A. Utami, "Traditional Market Sellers Acceptance of Electronic Government System," 2017 International Conference on Information Management and Technology (ICIMTech), pp. 284-287, 2017.

[17] S. Sono, N. L. Meilani, T. Prihyugiarto, and Y. Karyanti, "Analysis of the technology acceptance model (TAM) on survey system based smartphone by the national population and family planning Indonesia," 2018 6th International Conference on Information and Communication Technology, ICoICT 2018, pp. 394-401, 2018. 
INTENSIF, Vol.5 No.1 February 2021

ISSN: 2580-409X (Print) / 2549-6824 (Online)

DOI: https://doi.org/10.29407/intensif.v5i1.14477

[18] S. Perez, J. Cabrera, J. Rodriguez, and C. Raymundo, "E-Government Adoption Model Extended with Public Value in Peru," Proceedings of 2019 8th International Conference on Industrial Technology and Management-ICITM 2019, pp. 338-342, 2019.

[19] F. D. Davis, "Perceived usefulness, perceived ease of use, and user acceptance," MIS Quarterly, vol. 13, no. 3, pp. 319-339, 1989.

[20] J. F. J. Hair, G. T. M. Hult, C. Ringle, and M. Sarstedt, A Primer on Partial Least Squares Structural Equation Modeling (PLS-SEM). Thousand Oaks: Sage Publications, 2014.

[21] J. F. Hair, W. C. Black, B. J. Babin, and R. E. Anderson, "Multivariate Data Analysis," Vectors. Pearson Prentice Hall, United States America, p. 816, 2010.

[22] Indrawati and M. N. Has, "Examining Factors Influencing Webinar Adoption Using UTAUT Model (Case Study at Distance Learning Program, ABC University, BandungIndonesia 2016)," The 2016 IEEE Asia Pacific Conference on Wireless and Mobile (APWiMob), 2016.

[23] B. Kelana, A. Riskinanto, and D. R. Hilamawan, "The Acceptance of E-Payment among Indonesian Millennials," 2017 International Conference on Sustainable Information Engineering and Technology (SIET), pp. 348-352, 2017. 